\title{
Perceptions of the Effect of an EAP Course on English Self-efficacy and English Proficiency: Voices of International Students in China
}

\author{
Michael Agyemang Adarkwah ${ }^{1}$, Yu Zeyuan ${ }^{2}$ \\ ${ }^{1} \mathrm{PhD}$ candidate, Southwest University, China \\ ${ }^{2}$ Professor, Southwest University, China \\ Correspondence: Michael Agyemang Adarkwah, Southwest University, China.
}

Received: April 17, 2020

doi:10.5430/wjel.v10n2p1

\author{
Accepted: April 24, $2020 \quad$ Online Published: April 28, 2020 \\ URL: https://doi.org/10.5430/wjel.v10n2p1
}

\begin{abstract}
The English language has become an essential means for communication and studies for international students globally. With the increasing number of international students trooping to China to study diverse courses which are taught in the English medium, there is a need to address challenges faced by international students from non-native English speaking countries. The study adopted an embedded mixed-method approach where face-to-face interviews and focus group discussions were conducted on freshmen international students taking English for Academic Purposes (EAP) in a specific faculty of a university in China. The interviews were supplemented by the Questionnaire of English Self-Efficacy (QESE) to measure their perceived English self-efficacy after the course. An online questionnaire on English Course Evaluation (ECE) was used to measure the students' assessment of the course. The findings of the study offer insights into the effect of the intervention, challenges faced by students during the course, and suggestions on things to consider during the implementation of English courses for non-native English students in the future.
\end{abstract}

Keywords: English for Academic Purposes, self-efficacy, English self-efficacy, English proficiency, international students, non-native English students

\section{Introduction}

The increasing demand for English language skills as a result of globalization cannot be underestimated (Atai, Babaii, \& Nili-Ahmadabadi, 2018; Dali, 2017; Ebadi \& Zamani, 2018). This has called for the introduction of English for Academic Purposes (EAP) in Chinese colleges and universities (Dali, 2017; Han, Gao, \& Xia, 2019; Qian \& Jingxia, 2016). EAP is a course that enhances communication skills in English which are necessary for study purposes in formal education systems (Jordan, 1997). Although EAP courses can be complex even for native English speakers, Dali (2017) revealed that teaching and learning of EAP in Chinese universities do not turn out smoothly. The unsuccessful implementation of EAP was attributed to the lack of suitable textbook, frustrating teaching feedback, and the perceptions of students that EAP is boring and complex. In China, English also is used as a lingua franca in higher education as a medium of instruction and research (Qian \& Jingxia, 2016). The authors further opined that English is used as a medium of communication with people who do not understand or speak Chinese. Top-tier universities in China also require their students to publish in peer-reviewed English journals before they are granted their master's or $\mathrm{PhD}$ degree (Xu \& Li, 2018). Statistical report shows that as at 2018, there were 492,185 international students from 196 countries or areas studying in 1,004 higher education in 31 provinces or regions in China, with Asia accounting for the lion's share of international students, followed by Europe, and then Africa (Ministry of Education of the People's Republic of China, 2019).

International students contribute positively to institutions through academic contributions, tuition and diversity experience on school campus (Wang, Harrison, Cardullo, \& Lin, 2018). Although the main aim of international students is to pursue higher education, they face challenges; adapting to cultural differences, new social and cultural values, weather, and foods (Ma \& Wen, 2018; Rivas, Hale, \& Burke, 2019). One of the challenges international students faced in adapting to a new social and academic environment is with the use of the English Language (Perry, 2016; Rivas, Hale, \& Burke, 2019). The challenges associated with studying the English language can cause students to experience misunderstandings and negative interactions which would subsequently affect their learning negatively (Burdett \& Crossman, 2012). According to the researchers, international students' difficulty with the English Published by Sciedu Press 
language poses a greater threat than homesickness, cultural shock, and social difficulties that they face. They emphasize the need for improving the English proficiency level of international students and recommend universities to find ways to develop their competence in English. Perry (2016) posit that the provision of language support, such as online aid is an intervention that can help international students.

Higher education is mostly the period when teachers encounter cultural, linguistic, and ability differences of students (Lawyer, 2018). It is the responsibility of schools counsellors to create an environment where students from all multicultural backgrounds (languages, race, disability levels, and socioeconomic backgrounds) would be successful in their studies (Merlin-Knoblich \& Chen, 2018). The report by the Ministry of Education of the People's Republic of China (2019) revealed that the majority of international students coming to study in China were mostly from non-native English speaking countries. Non-native English speaking countries are where English is not the first language like the U.S. or Britain, but used as an additional language (Qian \& Jingxia, 2016). Higher institutions in China anticipate more English language degree programs in the future with the initiation of the "Belt and Road" project (Marsh, 2017). Amid the diversity of international students studying an English course to improve their English proficiency in this faculty of the selected university, the purpose of the research study is to know; the extent to which the EAP course enhanced students' English proficiency level, the challenges students faced during the course, strategies that can be employed during future implementation of the course, and how the students perceived their English self-efficacy after the course. Since both English self-efficacy and English proficiency have been linked to academic achievement and academic self-efficacy (Grisso, 2018; Kitikanan \& Sasimonton, 2017; Ozowuba, 2018; Ulibarri, Spencer, \& Rivas, 2013; Zhang, Ardasheva, Egbert, \& Ullrich-French, 2019), there is a need to address how students perceive the effectiveness of the English course. Students' voices on English for Academic purposes (EAP) have been well documented in literature (Ebadi \& Zamani, 2018; Gaffas, 2019; Hua \& Xuemei, 2015). Insights and suggestions from the students will help faculty leaders of higher institutions on the way forward during the implementation of an English course in the future.

\section{Literature Review}

Self-efficacy refers to an individual's awareness of his or her ability to perform a task in a particular domain (Chao, McInerney, \& Bai, 2019; Luangpipat, 2018; Malinauskas, 2017; Martin \& Rimm-Kaufman, 2015). It is also defined as a person's perception that he can undertake a course of action (Bartimote-Aufflicka, Bridgeman, Walker, Sharma, \& Smith, 2016). Self-efficacy is grounded in social cognitive theory by Bandura which considers "human behavior", "external environment", and "personal factors" as causal factors that are interrelated (Filatov \& Pill, 2015). Efficacious individuals outperform their counterparts who are not (Cave, Evans, Dewey, \& Hartshorn, 2018). Students with high self-efficacy are likely to overcome difficult tasks than those with low self-efficacy (Martin \& Rimm-Kaufman, 2015; Wu, 2016). While efficacious students make an effort to achieve their set goals, those who are not dwell on their shortcomings at school and makes little effort to achieve their set goals (Bandura, 1978; Corkett, Hatt, \& Benevides, 2011; Wang, Harrison, Cardullo, \& Lin, 2018). One significant predictor of high academic achievement at the university level is self-efficacy (Bartimote-Aufflicka, Bridgeman, Walker, Sharma, \& Smith, 2016; Schunk, Meece, \& Pintrich, 2013). Self-efficacy is directly related to the success of students (Chao, McInerney, \& Bai, 2019; Corkett, Hatt, \& Benevides, 2011; Wu, 2016).

English self-efficacy is "an individual's belief or confidence in his/her ability to use English language to communicate with others, understand English conversations, read materials, and write in English" (Wang, Harrison, Cardullo, \& Lin, 2018, p. 235). The researchers posited that the English self-efficacy level of an individual is strongly related to his/her English proficiency level. A study on EFL (English as a Foreign Language) Iranian learners revealed that there is a positive correlation between listening self-efficacy beliefs and listening comprehension ability (Tabrizi \& Saeidi, 2015). Another study by Rahimi \& Abedini (2009) also found a similar result. They found that the listening comprehension self-efficacy was closely related to listening proficiency of EFL learners. Academic writing is a challenge for native English speakers (Fadda , 2012) and international students (Eldaba \& Isbell, 2018). A survey of 40 Arab students studying in the United States revealed that the students have challenges with academic writing, and this was attributed to their educational background, inadequate preparation in their home countries, and different learning experiences (Zghyer, 2014). Bai \& Guo (2018) also found that writing is the most difficult skill for EFL learners in Hong Kong. They believe that self-efficacy is an essential factor in improving students' competence in writing. They further assert that students with higher self-efficacy put in more effort and persists to attain better academic achievement. A study of $139 \mathrm{EFL}$ undergraduates in China revealed that higher self-efficacy is closely related to higher use of reading strategies (Zhang, Ardasheva, Egbert, \& Ullrich-French, 2019). Zhang et al. further mentioned that there is a positive correlation between English language competency and self-efficacy. Students who perform well in English proficiency tests and earn good grades develop higher English 
self-efficacy level, however, the confidence level of students decrease when they earn poor grades in English test (Luangpipat, 2018). A moderate positive correlation exists between English self-efficacy and English reading comprehension (Balc1, 2017). English language self-efficacy predicts students' achievement in English (Chao, McInerney, \& Bai, 2019; Kim, Wang, Ahn, \& Bong, 2015; Zheng, Liang, \& Tsai, 2019). English self-efficacy affects the beliefs of students in language learning (Genç, Kuluşaklı, \& Aydın, 2016). The higher the English self-efficacy level of an English learning student, the higher the level of their academic achievement (Kitikanan \& Sasimonton, 2017).

Research appears to yield a contrasting result on the relationship between tests of English as a Foreign Language (TOEFL and IELTS) and the academic performance of students. Studies (Martirosyan, Hwang , \& Wanjohi 2015; Messner \& Liu 1995; \& Stoynoff, 1997) which investigated the relationship between TOEFL and students' academic performance among international students of different groups found out that there is a positive correlation between students' TOEFL scores and GPAs (Grade Point Average). A high score in English Proficiency tests such as TOEFL is associated with opportunities for better academic achievement (Choi, No, Jung, \& Lee, 2019). English fluency is related to students' self-efficacy (Shi, 2018). In addition, Shi stated that teaching learning strategies to students learning in English is a technique that can increase their self-efficacy. The academic achievement of students in a way depends on the language of instruction (Wilkinson \& Silliman, 2008). English proficiency was also found to have a positive impact on the academic performance of students (Geide-Stevenson, 2018; Maddah, 2019). A similar study by Maleki \& Zangani (2007) and Ghenghesh (2015) also showed that there is a positive correlation between the English proficiency level of students and their academic performance (Ghenghesh, 2015). Feast (2002) investigated the effect of IELTS (International English Language Testing System) on the academic performance of students in Australia and concluded that IELTS results have a positive correlation between the overall academic performance of students. Wilson \& Komba (2012) and Fakeye (2014) arrived at a consensus that English proficiency level (IELTS) has a significant impact on the academic performance of students. It was also found that there is a positive but weak correlation between IELTS and academic performance of international students, notably those from non-English speaking countries (Huong, 2001; Woodrow, 2006) Aiana, Ogundele \& Olanipekun (2013) found a different result in their study. According to them, English proficiency level does not correlate with study skills and has no impact on the academic performance of students. Arsad, Buniyamin \& Manan (2014) also found that the English proficiency level of a student has no direct or little effect on students' overall academic performance. Findings from Andrade (2009) study revealed that international students asserted that they had no problems with their academic achievement even if their English self-efficacy is low. A correlational study by Anyadubalu (2010) revealed that there is a weak negative correlation between self-efficacy and English language anxiety. He concluded that both self-efficacy and English language anxiety are predictors of English language performance. Ghenghesh (2015) recommend that higher institutions should be concerned with the English proficiency level of their students because it affects the learning engagement and academic performance.

\section{Theoretical Framework}

Pennycook (1997) asserted that teachers and students can act as change agents when using English for academic purposes. CEAP theory deals with English for Academic Purposes (EAP) issues where students, teachers, can voice their concerns and can change the state of education to a more satisfactory manner (Atai, Babaii, \& Nili-Ahmadabadi, 2018). According to the authors, CEAP includes taking into account cultural and social contexts. Benesch (2001) posited that CEAP advocates for all stakeholders in academia to express their concerns and demands through negotiation and questioning. (Benesch, 2001). Benesch emphasized that CEAP approach sees students, not as subordinates or novices, but rather active agents who can be encouraged to express their concerns and can collaborate with instructors or school leaders to establish an appropriate school program or curricula. Accommodations that can be made to a particular program as a result of CEAP includes course pedagogy and design, and academic behaviors and discourses (Helmer, 2013).

\section{Research Design}

The embedded mixed-method approach was used to triangulate the data collected. In an embedded research design, "one research approach is used in a primary role because it is the dominant or principal method of the study" (Ponce \& Pagán-Maldonado, 2015). In this study, qualitative data collected was supplemented by quantitative data. The objective of an embedded research design "is to use one of the research approaches to counter the deficiencies of the other" (Ponce \& Pagán-Maldonado, 2015). Two techniques were used to collect the data; the first was face-to-face interviews and focus group discussions (a qualitative approach), and the second was questionnaires (a quantitative approach). Qualitative and quantitative approaches were employed for triangulation of data. Triangulation "is the 
process of corroborating evidence from different individuals (e.g., a principal and a student), types of data (e.g., observational field notes and interviews), or methods of data collection (e.g., documents and interviews) in descriptions and themes in qualitative research" (Creswell, 2018, p. 259). Interviews were conducted to gain in-depth insight into the first two research questions, focus group discussions were held to get their shared views on strategies which can be employed in improving the English course, participants were made to answer an online questionnaire on English Course Evaluation (ECE), and finally, the Questionnaire for English Self-Efficacy (QESE) was administered to get their perceived English self-efficacy after the course.

\subsection{Research Questions}

R1. To what extent has the intervention enhanced students' English language proficiency?

R2. What are the challenges students faced during the intervention?

R3. What strategies should be employed during future implementation of the English course for international students?

R4. How do international students perceive their English self-efficacy after the intervention?

The researchers were also interested in testing whether there were significant mean differences between each of the four aspects of English self-efficacy among the educational level of the students.

H0. There will be no significant difference between each of the four aspects of English self-efficacy among the educational level of the students.

\subsection{Research Method}

The researcher adopted the case study approach to gain insights into the perceptions and observations of international students from non-native English speaking countries pursuing a degree in education (6 students in Education Leadership and Management program, 1 student in Economic and Management program, and 1 student in Curriculum and Instruction program) on an English course targeted to improve their English self-efficacy and English proficiency. Case study is an exploratory and descriptive approach that can be used to gain insights into perceptions (Faez \& Karas, 2019), and provide students with an opportunity to gain experiences and applied perspectives in order to address academic or career-related issues (Baron \& McNeal, 2019). A case study approach provides a chance for a particular group (such as students) to voice their concerns (Gaffas, 2019). The study was conducted in the first semester of the 2019-2020 academic year according to the academic calendar of the school.

\subsection{Instruments}

QESE: This questionnaire was formerly developed by Wang (2004) through verbal protocols, observations, and interviews of Chinese learners of English in the United States of America (USA). The questionnaire measures four aspects of English self-efficacy using eight questions for each aspect; listening $(1,3,9,10,15,22,24,27)$, speaking $(4,6,8,17,19,20,23,30)$, reading $(2,12,16,21,25,26,29,32)$ and writing $(5,7,11,13,14,18,28,31)$. The underlying reason why the questionnaire is randomly ordered was to prevent the awareness of the participants on each of the four aspects that were explored. The objective of the questionnaire was to ask the respondents to judge their capabilities in performing certain tasks using English as a foreign language. The questionnaire was in English. According to Gaffas (2019), QESE is more appropriate in terms of measuring the self-efficacy of students in the context of; listening, speaking, reading, and writing.

ECE: An online questionnaire of English Course Evaluation was used to measure how the students assess the effectiveness of the course in improving their English self-efficacy and proficiency. The tested and widely used online survey template was adopted from QuestionPro (a free survey software). The content of the questionnaire was assessed by gaining a researcher intuition.

Interviews: A semi-structured interview guide with a list of prepared questions was used to collect answers relating to the research questions to gain an in-depth understanding of the first two research questions. This was followed by a focus group discussion to answer the third research question ("What strategies should be employed during future implementation of the English course for international students?"). The interview guide allowed the interviewer to ask open-ended questions to encourage participants to expand their views on the subject matter. Interviews allow the researcher to probe into the behavior, perceptions, and feelings of the participants in a greater depth (Gaffas, 2019).

\subsection{Sampling}

The purposive sampling was used to identify the participants of the study. Participants of the study were eight (8) freshmen international students ( 2 males and 6 females) who came from 8 non-native English speaking countries. 
Immediately after completing the school registration, all freshmen (30 in total) international students at a particular faculty of the school were tested to know their English proficiency level using IELTS. An English class was organized for 9 of the students who recorded a low score in the test results for the entire semester (five months) to improve their English proficiency. Although students who are non-native English speakers prefer native English teachers in EAP courses because those teachers are considered as carriers of native English rather than non-native English teachers (Qian \& Jingxia, 2016), the teachers who instructed the students were Chinese teachers who had learned English as a second language. The 8 participants were chosen for the study because they were the freshmen, international students, at the faculty that enrolled in the English course. The total sample for the study was 8 because of the attrition of one student.

\subsection{Procedures}

The participants were informed about the aims of the study, and their informed consent was gained before the study began. They were informed that the researcher would ascribe pseudonyms to every participant. They were also assured that recorded data would be deleted to avoid any tracking of data. The researcher personally conducted face-to-face interviews and administered the questionnaires to the participants. Face-to-face interviews and focus group discussions were conducted in a classroom at the faculty of the university. All interviews and discussions were in English. QESE was adapted from Wang et al. (2013). QESE was personally administered to the research participants while ECE was filled online.

\subsection{Data Analysis}

The Statistical Package for Social Science (SPSS) 20.0 was used to analyze all quantitative data, while qualitative data were analyzed using content analysis. For the first two aims of the study (i.e. To identify the extent to which the intervention enhanced students English language proficiency and the challenges students faced during the course), face-to-face interviews were conducted and focus group discussions was conducted for the third aim of the study (i.e. To identify strategies that should be employed during future implementation of the EAP course). All interviews were conducted in English and transcribed by the researchers and organized into themes and sub-themes using NVivo Software 11.0. Pseudonyms were ascribed to each of the participants in interpreting interview data. To assess how students evaluated the course in general, the English Course Evaluation (ECE) survey was imported into the SPSS software, and the Likert scale items were analyzed using percentages. Descriptive statistics was used to analyze the items on the Questionnaire for English Self-Efficacy (QESE). Using the SPSS software, all subscales under each of the four aspects of self-efficacy were computed and averaged to give the total level. Each of the four aspects of self-efficacy (listening, speaking, reading, and writing) were measured with 8 questions. The scores are presented in number, minimum, maximum, mean, and standard deviation according to the aims of the study. To test the null hypothesis, one-way ANOVA was used to analyze the group differences of English self-efficacy based on the level of study of students.

\section{Findings and Discussions}

\subsection{Questionnaire of English Self-Efficacy (QESE)}

The Questionnaire of English self-efficacy (QESE) measures four skills of English language; listening, speaking, reading, and writing. For listening, the mean score is 6.03 out of $7(\mathrm{SD}=0.75)$. The maximum score for self-efficacy of listening is 6.75 , and the minimum score is 4.88 . As regards speaking, the mean score is 6.23 ( $\mathrm{SD}=0.47)$. The highest score for self-efficacy of speaking is 6.75, and its lowest score is 5.50. For Reading, the mean score is 6.27 $(\mathrm{SD}=0.56)$. The maximum score for self-efficacy of reading is 7.00 , and its minimum score is 5.50 . When it comes to writing, the mean score is 6.47 ( $\mathrm{SD}=0.54)$. The highest score for self-efficacy of writing is 7.00 , and its lowest score is 5.75. Table 1 and Figure 1 shows the descriptive statistics of the four aspects of English self-efficacy. The mean (average) scores of all the aspects of English self-efficacy are not significantly different from each other. However, the students perceived their English self-efficacy for reading and writing is higher than in listening and speaking. 
Table 1. Descriptive statistics of the mean scores of the four skills of English Language

\begin{tabular}{llllll}
$\begin{array}{l}\text { English } \\
\text { Self-Efficacy } \\
\text { Aspects }\end{array}$ & N & Minimum & Maximum & Mean & $\begin{array}{l}\text { Standard } \\
\text { Deviation (SD) }\end{array}$ \\
\hline Listening & 8 & 4.88 & 6.75 & 6.0313 & .74926 \\
Speaking & 8 & 5.50 & 6.75 & 6.2344 & .46979 \\
Reading & 8 & 5.50 & 7.00 & 6.2656 & .56076 \\
Writing & 8 & 5.75 & 7.00 & 6.4688 & .53765 \\
\hline
\end{tabular}

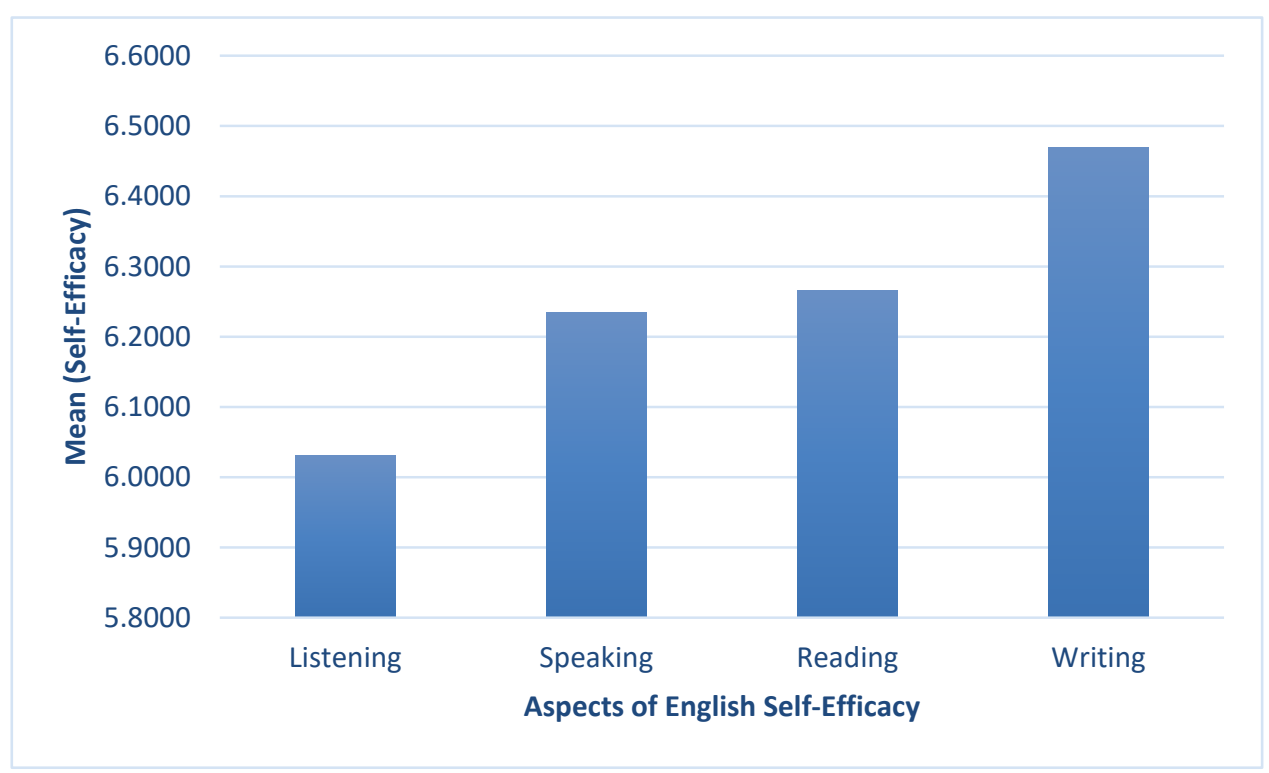

Figure 1. Mean Scores of the four aspects of English self-efficacy

\subsection{Group Differences}

To test the first null hypothesis, one-way ANOVA test was conducted to investigate the potential differences between each of the four aspects of English self-efficacy among the educational level of the students. Statistical test with significance level set at $\mathrm{p}=0.05$ was computed. The independent variable was student level (masters and $\mathrm{PhD}$ ) and the dependent variable was English self-efficacy (listening, speaking, reading, and writing). The means and standard deviations of the aspects of English self-efficacy among the educational level of the students are presented in table 2. Table 3 gives the ANOVA test results. The assumption of homogeneity of variances was tested and found tenable using Levene's test, $\mathrm{F}(1,6)=0.07, \mathrm{p}=0.05$.

Table 2. Descriptive statistics of English self-efficacy among educational level of students

\begin{tabular}{llll}
\hline & $\mathbf{N}$ & Mean & Std. Deviation \\
\hline Masters & 2 & 6.4844 & .33146 \\
PhD & 6 & 6.1719 & .61769 \\
Total & 8 & 6.2500 & .55601 \\
\hline
\end{tabular}

Table 3. ANOVA test of English self-efficacy among educational level of students

\begin{tabular}{llllll}
\hline & Sum of squares & df & Mean Square & F & Sig. \\
\hline Between & .146 & 1 & .146 & .436 & .534 \\
$\begin{array}{l}\text { Groups } \\
\text { Within Groups }\end{array}$ & 2.018 & 6 & .336 & & \\
Total & 2.164 & 7 & & & \\
\hline
\end{tabular}


The results indicate that there was no statistically significant mean difference of the aspects of English self-efficacy among the educational level of the students, $\mathrm{F}(1,436)=.534$. This supports the null hypothesis (H0).

\subsection{English Course Evaluation Survey (ECE)}

The results of the survey indicate that generally, the students perceived the course as good. However, a considerable amount of the students believed that the course did not meet their expectations. According to them, the quality of the examples provided was not good enough, and the quality of materials used was averagely good. Some believed that there was little diversity of content delivered to them during the English course. Student engagement and assessment materials like test were good. Close to half of the students expressed that the quality of the homework assignment and teaching method was not good. There was a little guest lecture, but class discussion and debates were good. The students believed the course helped them in individual reading and writing projects, but most of the students asserted that there were little role plays. As regards solving study cases, a significant amount of the students believed that it was poor, and they lacked the opportunity to make presentations in class (see Table 4).

Students were also asked to identify strategies they perceived will help improve in the English course when organized in the future. According to the students, the course should be able to improve their listening skills by using video and other related materials. They also highlighted that the course should be more pragmatic in nature rather than only writing essays, and teaching materials should include published dissertations and journal articles. Finally, the students suggested that the course should include a native English speaker when organized in the future.

Table 4. Percentages of the ECE survey response from the non-native international students

\begin{tabular}{|c|c|c|c|c|c|c|}
\hline \multirow{3}{*}{ No. } & \multirow[b]{2}{*}{ Specific Questions Asked in the Survey } & \multicolumn{5}{|c|}{ Percentages $(\%)$} \\
\hline & & Very & Poor & Fair & Good & Very \\
\hline & & Poor & & & & Good \\
\hline 1. & Overall, what do you think of this course? & & & & 83.33 & 16.67 \\
\hline 2. & $\begin{array}{l}\text { Level of relevance (compared to what you expected for an English } \\
\text { course for your grade) }\end{array}$ & & & 33.33 & 50.00 & 16.67 \\
\hline 3. & Quality of examples provided & & 16.67 & 33.33 & 33.3 & 16.67 \\
\hline 4. & Quality of materials provided (e.g. worksheets, ppt.) & & & 16.67 & 50.00 & 33.3 \\
\hline 5. & Diversity of format for the content delivered (audio, video) & 16.67 & & 33.33 & 50.00 & \\
\hline 6. & Level of student engagement & & & 33.33 & 50.00 & 16.67 \\
\hline 7. & $\begin{array}{l}\text { Quality of assessment materials (e.g. tests, portfolio requirements, } \\
\text { etc.) }\end{array}$ & & & 33.33 & 33.33 & 33.33 \\
\hline 8. & Quality of homework assessment & & & 33.33 & 50.00 & 16.67 \\
\hline 9. & Quality of teaching method used by the teacher & & & 33.33 & 66.67 & \\
\hline 10. & Guest lecture & & & 33.33 & 33.33 & 33.33 \\
\hline 11. & Class discussions and debates & & & & 50.00 & 50.00 \\
\hline 12. & Individual reading & & & 33.33 & 66.67 & \\
\hline 13. & Writing projects (e.g. essays) & & & 60.00 & 40.00 & \\
\hline 14. & Being involved in role plays & & & 50.00 & 33.33 & 16.67 \\
\hline 15. & Solving study cases & & 33.33 & 33.33 & 16.67 & 16.67 \\
\hline 16. & Being asked to hold presentations in front of the class & & 40.00 & 40.00 & & 20.00 \\
\hline
\end{tabular}




\subsection{Interview Results}

Table 5. Qualitative themes (categories) and sub-themes (sub-categories) from interview guide responses

\begin{tabular}{lll}
\hline \multicolumn{1}{c}{ Themes } & \multicolumn{1}{c}{ Sub-themes } \\
\hline Enhancement of English Self-Efficacy & $\circ$ Writing Skills \\
& $\circ \quad$ Reading Skills \\
& $\circ \quad$ Listening Skills \\
\hline Challenges & $\circ \quad$ Speaking Skills \\
& $\circ$ Class Assignment \\
& $\circ$ Academic Writing \\
& $\circ$ Lack of Class Presentations \\
& $\circ$ Academic Performance \\
\hline
\end{tabular}

\subsubsection{Enhancement of English Proficiency}

To investigate the extent to which the intervention has enhanced students' English language proficiency, the 8 students were interviewed. Most of the students felt that the intervention only improved their reading and writing skills. They reported that the intervention did not have any significant improvement on their listening and speaking.

Writing Skills: Majority of the students perceived that the EAP course improved their writing skills. They attributed the improvement in the writing skills to the essays they were tasked to write in class.

"On the writing skills, how to use some synonyms... how to do citations, how to do literature review... I think that is the part I improved more and more".

(Jane)

"The course improved my writing skills. I benefitted from writing assignments in class".

(Sharon)

"I think my English proficiency has increased very well since I joined the course in the first semester. More especially my English has improved in the writing skills”.

(Samuel)

Prior research has established that EAP has the ability to improve the writing skills of non-native English speaking students (Keefe \& Shi, 2017), and writing skills can be improved through essay writing (Davis \& Mahoney, 2005).

Reading Skills: The students also expressed that the EAP course gave them an opportunity to improve their reading skills. They attributed this to the skimming technique they developed during the course and some papers they read in the course of the instruction of the course.

"I think this course increased my reading skills. I am able to read some new words".

(Jane)

"I think all parts I improved, but the one I feel improved most is reading skills and writing skills". On the issue like skimming, how to read fast to find the main points on the paragraph. Also

(Sharon)

"Yes... the course improved my writing skills. Personally, I read some articles online after the course, and this helped me a lot."

(Irene)

Reading materials online, articles, notes given by teachers, and technical journals have been identified as a contributing factor to good reading ability (Irshad \& Anwar, 2018).

Speaking Skills: The general agreement of the students was that despite the intervention, the course had little effect on their speaking skills. The students asserted that they were not exposed to other contents (such as videos and audios) aside from the presentations of the teacher. Hence, they opined that the course did not 
help them to overcome their challenges with the speaking skills. One of the students also expressed concern about the difficulty in pronouncing words accurately. It was revealed that much emphasis was placed on the content of the textbook used on the course while there was little or no emphasis on speaking skills of the students.

"It couldn't improve my speaking skills. The course didn't focus on our speaking."

"My speaking did not change after the course. Although I tried to talk in class during class debates, I still have difficulty when pronouncing some English words".

"For me, I would say my speaking ability hasn't improved much after the course. We had discussions in class, but that did not help me to improve my speaking."

Alam \& Bashir (2013) posited that the deductive approach to teaching English does not place much emphasizes on the speaking and communicative skills. Speaking is one of the most important skills for students which is used in the academic context (Irshad \& Anwar, 2018).

Listening: A considerable amount of the student felt that the course did not increase their listening ability. The students reported that it might be because they did not have a native English teacher to teach the course. According to some of the students, they sometimes struggled to grasp the meaning of words during the class. It was also reported that they were no oral test to develop their listening skills.

"The course did not improve my listening... it is still a problem for me, especially when listening to some foreign songs in English."

(Irene)

"I find it hard to hear some words. I don't think my listening has improved during the course. Most of us were not ask to recite any words... maybe a native English teacher could have helped".

(Jane)

Listening has been identified as an essential skill for students learning English as a foreign language in English universities to excel in their respective fields of study (Chou, 2015).

\subsubsection{Challenges Faced During the Course}

Students in the study expressed difficulty in completing most of the assignments given by the instructor. They also asserted that they have a challenge when it comes to academic writing. The students reported that the lack of presentations in class could have been a contributing factor to why they perceive their listening and speaking skills hasn't improved.

Classroom Assignments: Few of the students believed they struggled with class assignments during the course. These students reported that some of the assignments were unfamiliar to them, and others were tedious. They believed they were exposed to class assignments which were unrelated to their final test.

II think I faced two main challenges during the course. First, when the teacher asked us to make a correction and to criticize a friend's homework. Secondly, when we were tasked to practice on how to create a survey questionnaire".

(Edna)

"The final exam was like IELTS, but we never had IELTS assignments in class. It was a challenge for me when we had to answer questions that were similar to the IELTS test.

(Irene)

Challenges associated with EAP learners in completing their assignments include choosing texts from appropriate sources, paraphrasing the texts, and using them to support their arguments (Yung \& Fong, 2019). 
Academic Writing: This challenge, according to some of the students were due to their struggle in using vocabulary and accurate English grammar. When asked on how they dealt with those challenges, they felt they didn't find any solution to their challenge, but they went through presentations given by their instructor to help them in dealing with those challenges.

"There were two big challenges for me, one was vocabulary, and the second one was English grammar. So... I can't find any solution for vocabulary, and errrh, the second one about English grammar, I go through the PowerPoint sent by the teachers to improve my English grammar".

(Jane)

"Academic writing is very hard for me because we have to write not only single sentence but complex and compound sentences. After the course, I have learned many techniques, and I also learned how to write from the internet".

(Gifty)

This finding is congruent with the statement of Eldaba \& Isbell (2018), who mentioned that one of the greatest challenges international students face is academic writing. They advocate for international students to gain competency not only in speaking the English language but also in writing academically.

Classroom Presentations: One of the main challenges students reported during the interview was their inability to get a chance in class to make presentations. They believed that their speaking couldn't improve because they had no chance to make a formal presentation in class.

"Yes errm... I think there must be a problem with the speaking of English especially for those who have not been exposed to the language itself because there were no presentations made by the students which would maybe enforce them to speak... so if they were only depending on writing and maybe listening that might cause a problem if they don't speak the language... so they also need to acquire skills in speaking".

(Saтиеl)

"The only presentations we had was from the teachers. No student was asked to stand in front of the class to make a presentation. Maybe the presentation could have helped us in our pronunciations."

(Jane)

Evans and Green (2007) conducted a survey using 500 undergraduates in Hong Kong who were having an EAP program to identify the needs of EAP students, and they concluded that students who are having EAP courses should be given the opportunity to make oral classroom presentations to enhance their English language learning abilities. One of the strategies identified to improve speaking skill is oral presentations (Chou, 2011)

Academic Performance: Students in the study were also asked if they perceived the challenges they faced can affect their future studies. Almost all the students asserted that the challenges could affect their future studies. The students also expressed concerns on the difficulties they may face with grammar their research.

"Yes they can affect my future studies because if I cannot be able to identify the topic sentence, that means I will be struggling to write parts of my dissertation such as the literature review".

(Sатиеl)

"Of course it will be a big loss for me if the course is not organized in the future because I have learned in the first semester, how to search keywords from big paragraphs, how to search ...errm... topic lines or topic sentence from a whole paragraph, and how to organize main ideas after reading a full text, so it was very helpful for me to start my research at the very beginning of my degree".

(Jane)

"I think the challenge is also writing skill or grammar in use. For me, it will affect my study a little, but I will try my best to solve the problem".

(Gifty)

"Yes. If the challenges I encountered is not solved, it can affect my future studies".

Previous studies have identified that there is a relationship between the English proficiency level of students and their academic performance (Aina, Ogundele, \& Olanipekun, 2013; Anyadubalu, 2010). 


\subsection{Focus Group Discussions}

A focus group discussion was held using the 8 students in the study to identify strategies to improve the teaching of the English course. Overall, they were happy with the initiative of the school leaders to organize an English course for them to enhance their command of English.

"Yes, I am happy, but it should be improved, and some teaching reading materials like related articles should be included in the course. The activity method is good, but we should be assigned more assignments about reading articles or making abstract of the articles.

(Cindy)

"Yes, I am happy. It was good, very interactive, and the teacher always gave feedback to us for all the tasks".

(Irene)

"Yes, I was somewhat happy with the way we were taught but not fully. We were only taught to some extent".

(Samuel)

Majority of the students were not satisfied with the teaching method and teaching materials, especially the textbook used during the course. They also complained about the workload of assignments during the course and also about the lack of presentations to improve their speaking skills and English self-efficacy. Students were somewhat satisfied with the teaching methods used during the course but also expected teachers should improve their instructional methods the next time the course is organized. It was identified that the activity method and didactic method of teaching was mostly used during the instruction of the course. The students suggested that teaching should be more interactive and learner-centered, and they should be given opportunities for class presentations. It was also suggested that there should be a correspondence between teaching materials used and the final test, which is organized for students who take the course.

"I like lecture and group discussions. I liked the teaching method but was not happy at all."

"Actually there was a book which was given by the teacher, it was very easy book. It has very very easy wording which is not too important for us. We have to learn any article or published material which can be helpful for us to learn academic reading and academic writing... and teachers often used activity methods, they use exercises given at the end of the textbook. They often used lecture method and activity method. This teaching methods only helped us to improve our reading in English, only in reading. The course didn't help us to improve our listening and our speaking."

(Jane)

"The material of the course and the posttest or final test need to be matched. If the final test will be like IELTS test, then the material and teaching method should be like IELTS preparation course”.

(Irene)

"The method the teacher used was not so much learner-centered and it was not so much on the teacher, there was integration. The teacher was involved and the learner as well but the problem was that we lacked the class presentation. I usually prefer a learner-centered method of teaching".

(Samuel)

"Yes. I agree with the school and suggest they should continue the course in future for next coming students and the one thing I want to add, the text and material which is launched by the school should be according to the level of academic writing so that it really helps the students. If the material is not according to the academic writing, it would be a wastage of time'.

(Sharon)

Some of the students also expressed that the length of the course was too short of having a full impact on their English proficiency and English self-efficacy. It was suggested by some students that the length of the course should be extended to two semesters (1 year).

"I think one semester is not enough for the course and this course should be taught in two semesters for one 
year. It would be very helpful to improve English, definitely academic English also”.

"I think the time was too short, in order to improve more skills, they should extend more time."

The students suggested that the school leaders should invite teachers whose first language is English to take the course rather than a foreign learner of English. They perceived they would have acquired more speaking and listening skills if the teacher was a native English speaker. This is consistent with the findings of Qian \& Jingxia (2016), who found out that students prefer native English speakers when it comes to EAP courses.

"I would like to suggest that they should invite native speaker teacher to teach in order to improve listening and speaking skills".

(Gifty)

\section{Conclusions and Implications}

The principal objective of the study was to investigate how freshmen international students who are non-native English speakers in a university in China perceived the effect of an EAP course on their English self-efficacy and English proficiency level. According to Andrade (2006), some of the support systems universities put in place for recruited students is to provide them with English language classes, tutorials, writing centers, and ensure international students improve academically and socially. Similar to the study conducted by Qian \& Jingxia (2016), students perceived that having a native English teacher would improve their English self-efficacy and English proficiency level. This is because students reported that the course only had a significant impact on their reading and writing skills, but minimal effect on their listening and speaking skills. They asserted that the challenges they faced during the course can have an impact on their future studies, which reinforces the findings in existing literature (Bai \& Guo, 2018; Chao, McInerney, \& Bai, 2019; Ghenghesh, 2015; Maddah, 2019; Martirosyan, Hwang , \& Wanjohi, 2015; Rahimi \& Abedini, 2009; Wilkinson \& Silliman, 2008). The evidence of the impact of English self-efficacy and English proficiency levels on the academic performance of students suggests that school leaders should pay much attention on how to improve EAP courses for students during implementation of the course in the future. Key among the strategies outlined by the students to improve the course is the use of published dissertations, journal articles, and high-quality textbooks for instruction in the EAP course. Students were much happy about the level of engagement and class discussion and debates. They also believed that writing essays organized in the class helped increased their self-efficacy in English writing and has ultimately improved their skills (Bai \& Guo, 2018). Some of the strategies outlined by the students to improved the course includes incorporating guest lectures into the instruction of the course, giving students opportunity to make classroom presentations in order to improve their speaking and writing skills, and using diverse contents in teaching. Another interesting finding from the study was that the educational level of students (whether Masters or $\mathrm{PhD}$ ) did not have a statistically significant effect on the English self-efficacy of the students which is in contrast to the findings of other existing literatures (Mirderikvand, 2016; Nasir \& Iqbal, 2019) which asserts that self-efficacy increases with a higher level of education.

There was evidence from both the interviews and surveys conducted that the EAP course is very important to their English language learning and academic efficacy (Atai, Babaii, \& Nili-Ahmadabadi, 2018; Dali, 2017; Jordan, 1997). Findings from both interviews and survey data also came to the same conclusion that the EAP course had the most effect on their reading and writing skills as compared to their listening and speaking ability. Another significant finding was that students opined the duration of the EAP course was too short of having a full impact on their English language learning. It was suggested that the course should be extended to two semesters when it is organized in the future. There was also correspondence between the data collected from the ECE survey and the focus discussions conducted when it comes to the kind of teaching method and materials used during the instruction of the course. Both data revealed that although there were class discussions and debates, the teaching method was didactic in nature and not more learner-centered. The students advocated for a more learner-centered approach during future implementation of the EAP course. As regards teaching materials, another strategy suggested by the students is the use of graphical presentations in the forms of videos and also audios to improve their listening and speaking abilities. Findings from the study generally imply that EAP courses are essential in improving the English language skills of non-native international students. Hence, much emphasizes should be placed upon addressing challenges associated with the implementation of EAP courses if departments in Chinese universities will instruct their students in the English medium. Geide-Stevenson (2018) believed that improvement in the English language could benefit students when it comes to their academic studies. 


\section{Recommendation for Future Research}

The study investigated the perceived effect of an EAP course on the English self-efficacy and English proficiency level of freshmen international students who are non-native English speakers in a specific faculty of a university in China. However, the results of the study are limited to the context of one university. The sample size for interviews, focus group discussions, and survey data was also small. The participants of the study were only freshmen graduate students. Also, the perspectives of teachers instructing EAP courses were not explored. It is recommended that researchers conducting a similar study should include the situation in other universities, use a large sample size to accurately reflect challenges with and strategies to improve EAP courses. Researchers should also explore teacher perspectives on the instruction and implementation of EAP courses.

\section{References}

Aina, J. K., Ogundele, A. G., \& Olanipekun, S. S. (2013). Students' proficiency in English language relationship with academic performance in science and technical education. American Journal of Educational Research, 9(1), 355-358.

Alam, Q., \& Bashir, U. A. (2013). Improving English oral communication skills of Pakistani public school's students. International Journal of English Language Teaching, 11(2), 17-36.

Andrade, M. S. (2006). International students in English-speaking universities: Adjustment factors. Journal of Research in International Education, 5(2), 131-154.

Anyadubalu, C. C. (2010). Self-efficacy, anxiety, and performance in the English language among middle-school students in English language program in Satri Si Suriyathai, Bankok. International Journal of Human and Social Sciences, 2(3), 193-198.

Arsad, P. M., Buniyamin, N., \& Manan, J. A. (2014). Students' English language proficiency and its impact on the overall student's academic performance: An analysis and prediction using neural network model. Wseas Transactions on Advances in Engineering Education, 11, 44-53.

Atai, M. R., Babaii, E., \& Nili-Ahmadabadi, M. (2018). A critical appraisal of university EAP programs in Iran: Revisiting the status of EAP textbooks and instruction. Journal of Language Horizons, Alzahra University, 2(1), $31-52$.

Bai , B., \& Guo, W. (2018). Influences of self-regulated learning strategy use on self-efficacy in primary school students' English writing in Hong Kong. Reading \& Writing Quarterly, 34(6), 523-536. https://doi.org/10.1080/10573569.2018.1499058

Balcı, Ö. (2017). The effects of learning-style based activities on students' reading comprehension skills and self-efficacy perceptions in English. Higher Education Studies, 7(4), 35-54. https://doi.org/10.5539/hes.v7n4p35

Bandura, A. (1978). Self-efficacy: Toward a unifying theory of behavioral change. Advances in Behaviour Research and Therapy, 1(4), 139-161. https://doi.org/10.1016/0146-6402(78)90002-4

Baron, A., \& McNeal , K. (2019). Case Study Methodology in Higher Education. USA: Advances in Higher Education and Professional Development (AHEPD) Book Series. https://doi.org/10.4018/978-1-5225-9429-1

Bartimote-Aufflicka, K., Bridgeman, A., Walker, R., Sharma, M., \& Smith, L. (2016). The study, evaluation, and improvement of university student self-efficacy. Studies in Higher Education, 41(11), 1918-1942. https://doi.org/10.1080/03075079.2014.999319

Benesch, S. (2001). Critical English for academic purposes: Theory, politics and practice. London: New York. https://doi.org/10.4324/9781410601803

Burdett, J., \& Crossman, J. (2012). Engaging international students: An analysis of the Australian Universities Quality Agency (AUQA) reports. Quality Assurance in Education, 20(3), 207-222. https://doi.org/10.1108/09684881211240286

Cave, P. N., Evans, N. W., Dewey, D. P., \& Hartshorn, K. J. (2018). Motivational partnerships: increasing ESL student self-efficacy. ELT Journal, 72(1), 83-96. https://doi.org/10.1093/elt/ccx027

Chao, C. N., McInerney, D. M., \& Bai, B. (2019). Self-efficacy and self-concept as predictors of language learning. Asia-Pacific Education Research, 28(2), 139-147. https://doi.org/10.1007/s40299-018-0420-3 
Choi, N., No, B., Jung, S., \& Lee, S. E. (2019). What affects middle school students' English anxiety in the EFL context? Evidence from South Korea. Education Sciences, 39(9), 1-11. https://doi.org/10.3390/educsci9010039

Chou, M. H. (2011). The influence of learner strategies on oral presentations: A comparison between group and individual performance. English for Specific Purposes, 30(4), 272-285. https://doi.org/10.1016/j.esp.2011.04.003

Chou, M. H. (2015). The influence of topics on listening strategy use for English for Academic Purposes. English Language Teaching, 8(2), 44-54. https://doi.org/10.5539/elt.v8n2p44

Corkett, J., Hatt, B., \& Benevides, T. (2011). Student and teacher self-efficacy and the connection to reading and writing. Canadian Journal of Education, 34(1), 65-98.

Creswell, J. W. (2018). Research design: qualitative, quantitative, and mixed methods approaches (Fifth edition ed.). Los Angeles: SAGE.

Dali, N. (2017). The construction of EAP textbooks in Chinese context from the perspective of eco-education theory. English Language Teaching, 10(5), 214-221. https://doi.org/10.5539/elt.v10n5p214

Davis, W., \& Mahoney, K. (2005). The effects of grammar testing on the writing quality and reduction of errors in college freshmen's essays. Dalton, Georgia: Division of Humanities, Dalton State College.

Ebadi, S., \& Zamani, G. (2018). Predatory publishing as a case of symbolic violence: A critical English for academic purposes approach. Cogent Education, 5, 1-25. https://doi.org/10.1080/2331186X.2018.1501889

Eldaba, A. A., \& Isbell, J. K. (2018). Writing gravity: International female graduate students' academic writing experiences. Journal of International Students, 8(4), 1879-1890. https://doi.org/10.32674/jis.v8i4.236

Fadda , H. A. (2012). Difficulties in academic writing: From the perspective of King Saud university postgraduate students. English Language Teaching, 5(3), 123-130. https://doi.org/10.5539/elt.v5n3p123

Faez, F., \& Karas, M. (2019). Language proficiency development of non-native English-speaking teachers (NNESTs) in an MA TESOL program: A case study. The Electronic Journal for English as a Second Language, 22(4), $1-16$.

Fakeye, D. (2014). English language proficiency as a predictor of academic achievement among EFL students in Nigeria. Journal of Education and Practice, 5(9), 38-41.

Feast, V. (2002). The impact of IELTS scores on performance at university. International Education Journal, 3(4), 70-85.

Filatov, K., \& Pill, S. (2015). The relationship between university learning experiences and English teaching self-efficacy: perspectives of five final-year pre-service. Australian Journal of Teacher Education, 40(6), 33-59. https://doi.org/10.14221/ajte.2015v40n6.3

Gaffas, Z. M. (2019). Students' perceptions of the impact of EGP and ESP courses on their English language development: Voices from Saudi Arabia. Journal of English for Academic Purposes, 42, 1-13. https://doi.org/10.1016/j.jeap.2019.100797

Geide-Stevenson, D. (2018). Does English proficiency affect academic performance? International Review of Economics Education, 28, 41-48. https://doi.org/10.1016/j.iree.2018.04.002

Genç, G., Kuluşaklı, E., \& Aydın, S. (2016). Exploring EFL Learners’ perceived self-efficacy and beliefs on English language learning. Australian Journal of Teacher Education, 41(2), 53-68. https://doi.org/10.14221/ajte.2016v41n2.4

Ghenghesh, P. (2015). The relationship between English language proficiency and academic performance of university students - Should academic institutions really be concerned? International Journal of Applied Linguistics \& English Literature, 4(2), 1-7. https://doi.org/10.7575/aiac.ijalel.v.4n.2p.91

Grisso, L. C. (2018). The Relationship between English language proficiency and academic achievement in English language learners. Lynchburg, VA: Liberty University.

Han, S. (2019, September 23). Number of foreign students studying in China 2016, by country of origin. China. Retrieved from https://www.statista.com/statistics/430717/china-foreign-students-by-country-of-origin/ 
Han, Y., Gao, X., \& Xia, J. (2019). Problematising recent developments in non-English foreign language education in Chinese universities. Journal of Multilingual and Multicultural Development, 40(7), 562-575. https://doi.org/10.1080/01434632.2019.1571072

Helmer, K. A. (2013). Critical English for academic purposes: Building on learner, teacher, and program strengths. Journal of English for Academic Purposes, 12, 273-287. https://doi.org/10.1016/j.jeap.2013.08.003

Hua, Q., \& Xuemei, L. (2015). Voices of Chinese Post-80s Students in English Academic Writing. TESL-EJ, 19(3), $1-15$.

Huong, T. (2001). The predictive validity of the International English Language Testing System (IELTS). Post-Script, 2(1), 66-94.

Irshad, I., \& Anwar, B. (2018). Designing English for specific purposes course for computer science students. Journal of Education and Educational Developement, 5(1), 156-171. https://doi.org/10.22555/joeed.v5i1.1533

Jordan, R. R. (1997). English for Academic Purposes (A guide and resource book for teachers). Cambridge University Press. https://doi.org/10.1017/CBO9780511733062

Keefe, K., \& Shi, L. (2017). An EAP Program and Students' Success at a Canadian University. TESL Canada Journal, 34(2), 1-24. https://doi.org/10.18806/tesl.v34i2.1264

Kim, D. H., Wang, C., Ahn, H. S., \& Bong, M. (2015). English language learners' self-efficacy profiles and relationship with self-regulated learning strategies. Learning and Individual Differences, 38, 136-142. https://doi.org/10.1016/j.lindif.2015.01.016

Kitikanan, P., \& Sasimonton, P. (2017). The Relationship between English self efficacy and English learning achievement of L2 Thai Learners. Language Education and Acquisition Research Network (LEARN) Journal, 10(1), 149-164. https://doi.org/10.5539/elt.v10n12P72

Kitikanan, P., \& Sasimonton, P. (2017). The Relationship between English Self-efficacy and English Learning Achievement of L2 Thai Learners. Language Education and Acquisition Research Network (LEARN) Journal, 10(1), 148-163. https://doi.org/10.5539/elt.v10n12P72

Lawyer, G. (2018). The dangers of separating social justice from Multicultural Education: Applications in higher education. International Journal of Multicultural Education, 20(1), 86-101. https://doi.org/10.18251/ijme.v20i1.1538

Lin, J., Hughes, R., Long, D., \& Kim, D. (2016). Characteristics of English language learners. Phiadelphia: Philadelphia Education Research Consortium.

Luangpipat, N. (2018). Sources of self-efficacy of English language learners with individual differences. Electronic Journal of Research in Educational Psychology, 16(1), 79-108. https://doi.org/10.25115/ejrep.v16i44.1938

Ma, J., \& Wen, Q. (2018). Understanding international students' in-class learning experiences in Chinese higher education institutions. Higher Education Research \& Development, 37(6), 1186-1200. https://doi.org/10.1080/07294360.2018.1477740

Maddah, H. A. (2019). Impact of English proficiency and bilingual Instructions on the student performance: A Hypothetical Study. Journal of Education and Human Development, 8(2), $42-48$. https://doi.org/10.15640/jehd.v8n2a6

Maleki, A., \& Zangani, E. (2007). A survey on the relationship between English language proficiency and the academic achievement of Iranian EFL students. Asian EFL Journal, 9(1), 86-96.

Malinauskas, R. K. (2017). Enhancing of self-efficacy in teacher education students. European Journal of Contemporary Education, 6(4), 732-738. https://doi.org/10.13187/ejced.2017.4.732

Marsh, N. (2017, March 28). China sees 11\% growth of international student enrolments. China. Retrieved from https://thepienews.com/news/china-11-percent-growth-international-student/

Martin, D. P., \& Rimm-Kaufman, S. E. (2015). Do student self-efficacy and teacher-student interaction quality contribute to emotional and social engagement in fifth grade math? Journal of School Psychology, 53(5), 359-373. https://doi.org/10.1016/j.jsp.2015.07.001

Martirosyan, N. M., Hwang , E., \& Wanjohi, R. (2015). Impact of English proficiency on academic performance of international students. Journal of International Students, 5(1), 60-71. 
Merlin-Knoblich, C., \& Chen, J. A. (2018). A survey of school counselor multicultural education behaviors and the obstacles that impede them. Journal of School Counseling, 16(22), 1-33.

Messner, E. P., \& Liu, N. (1995). The test of English as a foreign language: Examination of the "cut-off scores" in US universities. International Journal of Educational Management, 9(2), 39-42. https://doi.org/10.1108/09513549510082378

Ministry of Education of the People's Republic of China. (2017, March 01). 2016 nian quanguolaihualiuxuesheng shujutongji [National statistics for international students studying in China in 2016]. Retrieved from http://www.moe.gov.cn/jyb_xwfb/xw_fbh/moe_2069/xwfbh_2017n/xwfb_170301/170301_sjtj/201703/t201703 01_297677.html

Ministry of Education of the People's Republic of China. (2019, April 18). Statistical report on international students in China for 2018. China.

Mirdehghan, M., HoseiniKargar, N., Navab, S., \& Mahmoodi, T. (2011). Cultural barriers: Pros and cons on ELT in Iran. International Journal of English Linguistics, 1(1), 15-20. https://doi.org/10.5539/ijel.v1n1p15

Mirderikvand, F. (2016). The relationship between academic self-efficacy with level of education, age and sex in Lorestan University students. Journal of Chemical and Pharmaceutical Research, 8(2), 355-358.

Nasir, M., \& Iqbal, S. (2019). Academic self-efficacy as a predictor of academic achievement of Students in pre-service teacher training programs. Bulletin of Education and Research, 41(1), 33-42.

Ozowuba, G. U. (2018). Relationship between English proficiency and academic achievement of Nigerian secondary school students. Walden University.

Pennycook, A. (1997). Vulgar pragmatism, critical pragmatism and EAP. English for specific purposes, 16(4), 253-269. https://doi.org/10.1016/S0889-4906(97)00019-7

Perry, C. J. (2016). Comparing international and American students' challenges: A Literature Review. Journal of International Students, 6(3), 712-721.

Ponce, O. A., \& Pagán-Maldonado, N. (2015). Mixed methods research in education: Capturing the complexity of the profession. International Journal of Educational Excellence, 1(1), 111-135. https://doi.org/10.18562/IJEE.2015.0005

Qian, Y., \& Jingxia, L. (2016). Chinese college students' views on native English and non-native English in EFL classrooms. Advances in Language and Literary Studies, 7(4), 84-94. https://doi.org/10.7575/aiac.alls.v.7n.4p.84

Rahimi, A., \& Abedini, A. (2009). The interface between EFL learners' self-efficacy concerning listening comprehension and listening proficiency. Novitas Royal, 3(1), 14-28.

Rivas, J., Hale, K., \& Burke, M. G. (2019). Seeking a sense of belonging: Social and cultural integration of international students with American college students. Journal of International Students, 9(2), 687-703.

Schunk, D. H., Meece, J. R., \& Pintrich, P. R. (2013). Motivation in Education: Theory, Research, and Applications (4th ed.). Upper Saddle River, N.J: Pearson.

Shi, H. (2018). English language learners' strategy use and self-efficacy beliefs in English language learning. Journal of International Student, 8(2), 724-741. https://doi.org/10.32674/jis.v8i2.101

Stoynoff, S. (1997). Factors associated with international students' academic achievement. Journal of Instructional Psychology, 24(1), 56-68.

Tabrizi, H. M., \& Saeidi, M. (2015). The relationship among Iranian EFL learners' self-efficacy autonomy and listening comprehension ability. English Language Teaching, 8(12), 158-169. https://doi.org/10.5539/elt.v8n12p158

Ulibarri, D. M., Spencer, M. L., \& Rivas, G. A. (2013). Language Proficiency and academic achievement: A study of language proficiency tests and their relationship to school ratings as predictors of academic achievement. Bilingual Research Journal, 5(3), 47-80. https://doi.org/10.1080/08855072.1981.10668410

Wang, C. (2004). Self-regulated learning strategies and self-efficacy beliefs of children learning English as a second language. Doctoral dissertation. Retrieved from http://www.ohiolink.edu/etd/ 
Wang, C., Kim, D. H., Bong, M., \& Ahn, H. S. (2013). Examining measurement properties of an English self-efficacy scale for English language learners in Korea. International Journal of Educational Research, 59, 24-34. https://doi.org/10.1016/j.ijer.2013.02.004

Wang, C.-h., Harrison, J., Cardullo, V., \& Lin, X. (2018). Exploring the relationship among international students' english self-efficacy, using english to learn self-efficacy, and academic self-efficacy. Journal of International Students, 8(1), 233-250. https://doi.org/10.32674/jis.v8i1.163

Wilkinson, L., \& Silliman, E. (2008). Academic language proficiency and literacy instruction in urban settings. In L. Wilkinson, L. Morrow, \& V. Chou (Eds.), Improving Literacy Achievement in Urban Schools. Critical Elements in Teacher Preparation. Newark, DL: International Reading Association.

Wilson, J., \& Komba, S. C. (2012). The link between English language proficiency and academic performance: A pedagogical perspective in Tanzanian secondary schools. World Journal of English Language, 2(4), 1-10. https://doi.org/10.5430/wjel.v2n4p1

Woodrow, L. (2006). Academic success of international postgraduate education students and the role of English proficiency. University of Sydney Papers in TESOL, 1, 51-70.

Wu, Y. (2016). Universal beliefs and specific practices: students' math self-efficacy and related factors in the United States and China. International Education Studies, 9(12), 61-74. https://doi.org/10.5539/ies.v9n12p61

Xu, X., \& Li, X. (2018). Teaching academic writing through a process-genre approach: A pedagogical exploration of an EAP program in China. The Electronic Journal for English as a Second Language, 22(2), 1-21.

Yung, K. W. H., \& Fong, N. (2019). Learning EAP at university: Perceptions of high-achieving first-year ESL undergraduates. ELT Journal, 73(3), 306-315. https://doi.org/10.1093/elt/ccz019

Zghyer, A. (2014). Arab students' difficulties with English writing during their transition to the United States: An exploratory study. (Doctoral dissertation). Available from ProQuest Dissertations and Theses. (UMI No. 3640931).

Zhang, X., Ardasheva, Y., Egbert, J., \& Ullrich-French, S. C. (2019). Building assessments for self-efficacy in English public speaking in China. The Asia-Pacific Education Researcher, 28(5), 411-420. https://doi.org/10.1007/s40299-019-00441-9

Zheng, C., Liang, J. C., \& Tsai, C. C. (2019). Validating an instrument for EFL Learners' sources of self-efficacy, academic self-efficacy and the relation to English proficiency. The Asia-Pacific Education Researcher, 26(6), 329-340. https://doi.org/10.1007/s40299-017-0352-3 